\title{
PEMBANGUNAN PORTAL WEB CROWDSOURCING EVENT PERGURUAN TINGGI MENGGUNAKAN METODE ITERATIVE INCREMENTAL (MODUL PESERTA EVENT)
}

\author{
${ }^{1}$ Alifia Indra Damarani, ${ }^{2}$ Irfan Darmawan, ${ }^{3}$ Taufik Nur Adi \\ 1,2,3 Program Studi Sistem Informasi, Fakultas Rekayasa Industri, Telkom University \\ 1'alifia.indra@gmail.com, ${ }^{2}$ dirfand@gmail.com, ${ }^{3}$ taufiknuradi@gmail.com
}

\begin{abstract}
Abstrak-Perguruan Tinggi merupakan instansi yang paling sering mengadakan event. Event dibutuhkan sebagai wadah untuk mahasiswa berkreasi, meningkatkan kemampuan dalam berorganisasi, menjadi ajang hiburan bagi mahasiswa dan masyarakat luas. Portal event perguruan tinggi yang ada pada saat ini belum mengakomodir kemudahan pencarian event dan belum memudahkan user dalam mendaftarkan diri di suatu event. Untuk mengatasi permasalahan tersebut, dibangun sebuah portal website event perguruan tinggi dengan menggunakan metode iterative \& incremental disertai konsep crowdsourcing dimana website yang bersifat terbuka dengan menampilkan pengkategorian informasi yang jelas sehingga pengunjung tidak merasa kebingungan untuk menemukan informasi yang diinginkan dan meningkatkan kontribusi pengunjung atau peserta event pada portal web yang dibangun. Analisis dan perancangan dari portal website ini menggunakan UML dan pembangunan portal menggunakan bahasa pemrograman PHP dengan framework Laravel. Portal website diuji dengan melakukan verifikasi fungsionalitas sistem dan validasi dari user feedback. Hasil pengujian menunjukan bahwa portal telah dibangun sesuai dengan perancangan dan dapat mempermudah pihak peserta untuk mencari informasi dan membeli tiket event. Saran untuk penelitian ini adalah menambahkan beberapa fitur dan memperbaiki desain web portal.
\end{abstract}

Kata kunci : crowdsourcing, event, iterative incremental

\section{Pendahuluan}

Event (acara) yang diselenggarakan Perguruan Tinggi sangat beragam jenisnya, seperti seminar, festival, workshop, konser musik, kajian keagamaan, lomba atau kompetisi, olahraga, gabungan antar event-event tersebut, dan lain-lain. Salah satu kunci sukses atau sekaligus kegagalan penyelenggaraan event adalah pengunjung atau peserta. Hal ini tentunya berkaitan dengan jumlah peserta yang mendaftar atau jumlah pengunjung yang diharapkan hadir pada suatu event sesuai dengan target yang telah ditetapkan [1].

Grafik data pengguna internet Indonesia yang bersumber dari situs resmi APJII (Asosiasi Penyedia Jasa Internet Indonesia) memperlihatkan bahwa penggunaan internet dan teknologi berkembang sangat pesat di Indonesia. Pada tahun 2015 diprediksi pengguna internet di Indonesia mencapai 139 juta jiwa. Hal ini menandakan bahwa media publikasi dapat dimaksimalkan dengan menggunakan internet untuk memperluas area publikasi, misalnya melalui portal web event. Oleh karena itu, untuk membantu calon peserta event menemukan event yang dicari, dibutuhkan kemudahan akses informasi mengenai event tersebut melalui media publikasi.
Berdasarkan paparan permasalahan yang dialami peserta event, produk penelitian yang dilakukan yaitu membangun portal web event perguruan tinggi berbasis crowdsourcing bernama acarakampus.com yang menjembatani kebutuhan peserta event untuk mencari event sesuai dengan kebutuhan.

\section{Metode Penelitian}

Pada bagian ini akan dijelaskan tentang metode penelitian tapi lebih ditekankan pada model konseptual, dimana model konseptual merupakan konsep pemikiran yang dapat membantu peneliti untuk merumuskan pemecahan masalah dan membantu dalam merumuskan solusi dari pemasalahan yang ada.

Portal event perguruan tinggi ini dibuat dengan menerapkan metode crowdsourcing dimana input dari sistem ini adalah data event dan data calon peserta event (sources) dari user selaku penyelenggara event dan masyarakat luas (crowd). Dengan menerapkan metode tersebut, maka setiap user mampu memberikan kontribusinya dengan maksimal.

Crowdsourcing sendiri dipilih karena crowdsourcing merupakan pengembangan dari konsep outsourcing. Istilah outsourcing (alih daya) sendiri berasal dari kata "out" dan "source" yang berarti sumber dari luar, merupakan pendekatan manajemen yang memberikan kewenangan pada sebuah agen luar (pihak ketiga) untuk bertanggung jawab terhadap proses atau jasa yang sebelumnya dilakukan oleh perusahaan [2]. Portal web acara ini dijalankan dengan kontribusi langsung dari penggunanya (calon peserta dan penyelenggara acara) untuk saling berinteraksi dan berbagai dengan tujuan mempublikasikan acara atau berpartisipasi dalam suatu acara.

Dalam perancangan portal web acara berbasis crowdsourcing metode yang digunakan adalah iteratif dan incremental. Melihat sistem informasi ini yang tergolong baru dan masih membutuhkan requirement yang jelas maka dibutuhkan model yang fleksibel dan dapat berulang jika terjadi perubahan kebutuhan. Dengan menggunakan metode tersebut, perbaikan dalam tahapan pengembangan sistem menjadi lebih fleksibel (setiap tahapan dari SDLC dilakukan secara berulang, dapat dikerjakan secara bersamaan, serta dapat kembali ke tahapan sebelumnya apabila akan dilakukan perubahan-perubahan tertentu dalam rancangan pengembangan sistem). Selain itu model ini juga memerlukan 
cost yang rendah, sehingga relevan untuk sistem yang memiliki resource terbatas dan belum ditentukan secara pasti.

Menurut (Rational Software Development Company, 1998 $)^{[3]}$ Dalam Best Practices For Software Development Time Metode Iterative Incremental memiliki siklus pengembangan yang terdiri dari empat fase utama, yaitu Inception, Elaboration, Construction, dan Transition. Setiap siklus meliputi satu atau beberapa iterasi. Hanya saja pada jurnal ini hanya dicantumkan hasil iterasi terakhirnya. Berikut detail pengerjaan berdasarkan fase-fase yang ada:

1. Inception

Tahap Inception merupakan tahap awal untuk menganalisa kebutuhan sistem yang akan dibangun. Pada tahap Inception ini menitik beratkan pada fase business modeling dan requirement analysis

\section{Elaboration}

Tahap elaboration merupakan tahap setelah inception dimana di dalam setiap tahap terdapat beberapa fase iterative. Pada tahap elaboration ini lebih menitikberatkan pada fase analysis dan design dimana akan dibuat sequence diagram, class diagram, conseptual data model dan physical data model

\section{Contruction}

Tahap construction ini lebih menekankan pada fase implementation dimana akan dilakukan deployment sistem mengikuti deployment diagram dan implementasi komponenkomponen sistem.

\section{Transition}

Tahap transition ini lebih menitikberatkan pada fase testing dimana akan dilakukan pengujian blackbox terhadap sistem dimulai dengan membangun rencana pengujian, kasus uji dari rencana pengujian tersebut, kemudian akan diambil juga feedback dari user mengenai sistem ini

Modul peserta acara ini, lebih mengarah pada manajemen peserta yang melingkupi pendaftaran pada web portal disertai login, manajemen akun pesrta dan penyelenggara, menampilkan informasi detail acara yang akan berlangsung, registrasi acara beserta payment, kemampuan pencarian acara sesuai kebutuhan, report spam, pengiriman pesan ke penyelenggara acara dan pengunjung portal web dapat menandai acara yang diminati . Fungsi-fungsi tersebut akan disajikan melalui fitur registrasi, pencarian advanced, bookmark, contact organizer, user profile dan daftar acara. Penggambaran metode konseptual dalam penelitian ini yang sesuai penjabaran diatas dapat dilihat pada Gambar 1.

\section{HASIL DAN PEMBAHASAN}

Pada bagian ini akan dijelaskan bagian proses pengerjaan yang dilaksanakan baik dari taha $\mathrm{p}$ analisis dan perancangan hingga dianggap selesai atau berhasil berdasarkan model konseptual yang telah dijabarkan sebelumnya.

\section{A. Business Modelling}

Business model menggambarkan bagaimana aplikasi ini mendapatkan revenue dengan tujuan aplikasi dapat dikembangkan sesuai dengan kebutuhan user [4].

Berikut penjelasan business modelling pada Gambar 2:

a. Key Partners yang berfungsi mengembangkan aplikasi yang dirancang antara lain event organizer, event publisher. memperkenalkan web portal yang dibuat kepada customer segment yang membutuhkan ditangani oleh event publisher.

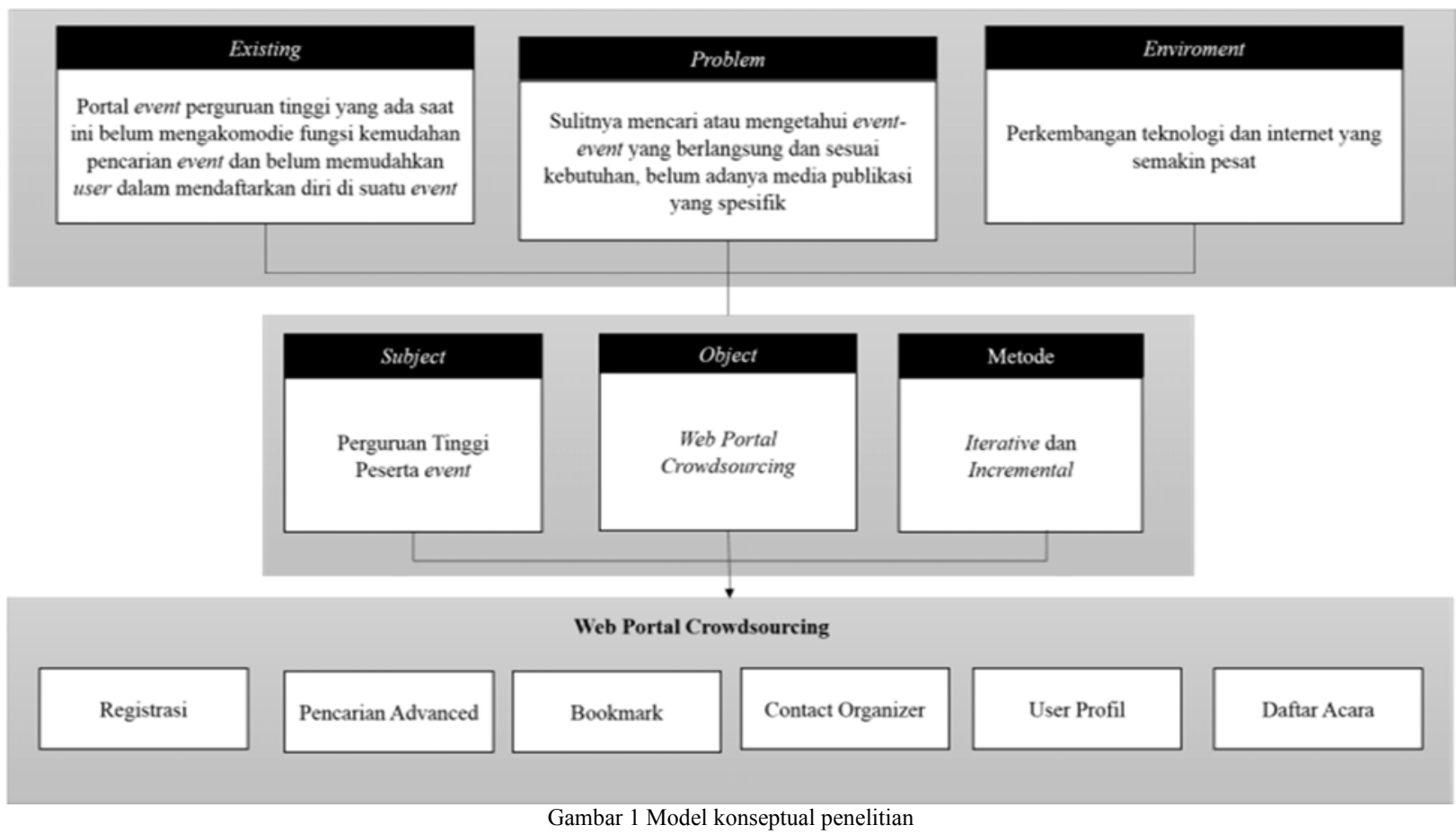




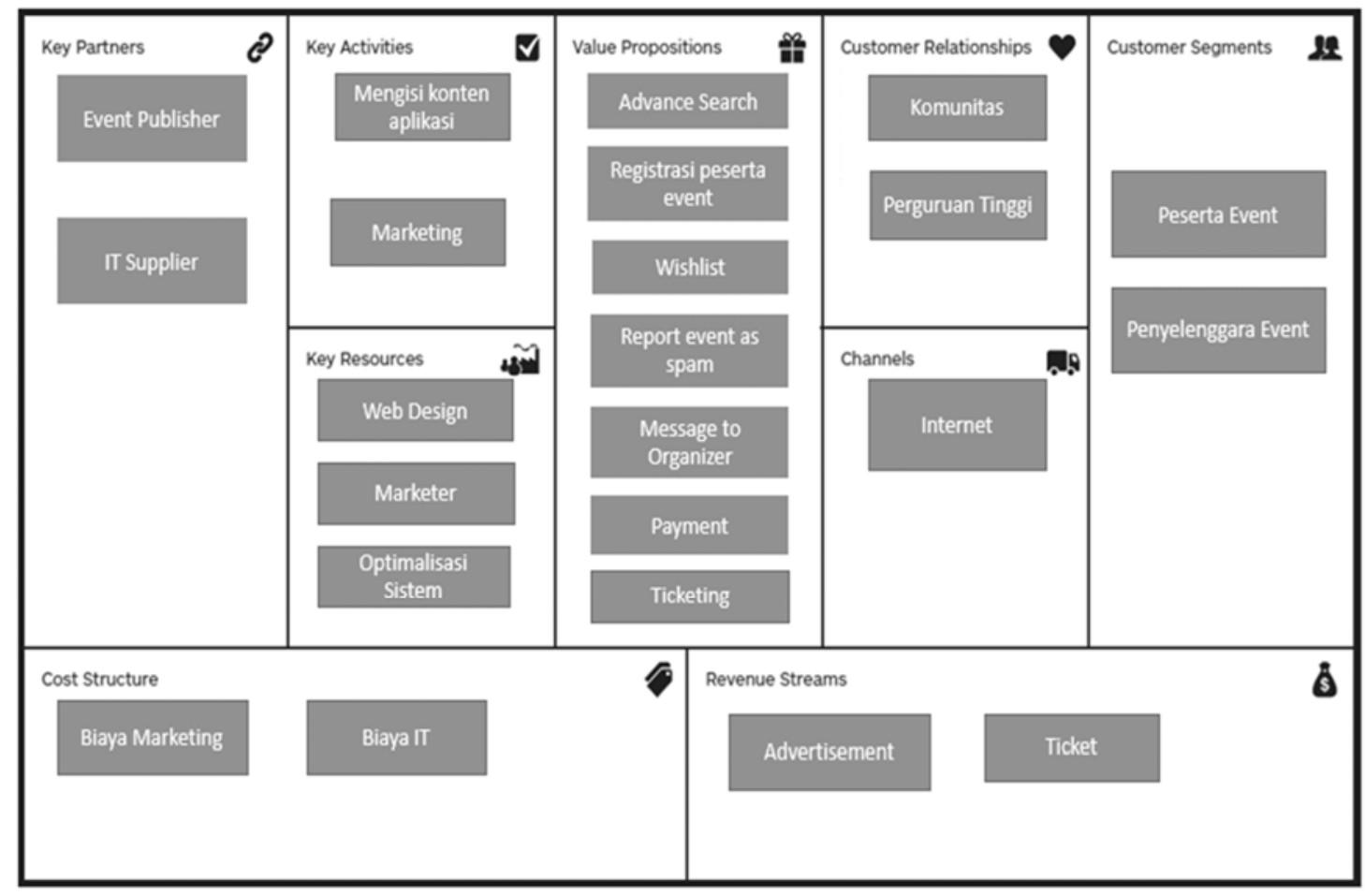

Gambar 2 Business modelling web portal acarakampus.com

b. Key Activity pada aplikasi ini merupakan pengisian konten acara dan kegiatan marketing, dimana semakin banyak informasi yang di-posting oleh user maka akan menunjukan trafik yang baik pada aplikasi yang dibuat. Sementara marketing yang dimaksud adalah kegiatan memperkenalkan aplikasi ini sekaligus mengajak user untuk berkontribusi.

c. Key Resources atau sumber daya utama dari aplikasi ini adalah web design dan optimalisasi sistem.

d. Value Propositions yang diberikan oleh aplikasi ini terbagi menjadi lima bagian besar yaitu, advanced search, Wishlist, Report event as spam, Contact the organizer dan ticketing. Advance search memudahkan pengunjung untuk menemukan event yang diinginkan dengan cepat dan tepat. Fitur wishlist membantu member menyimpan acara yang ada untuk dilihat dikemudian hari. Untuk meningkatkan kepuasan member juga disediakan fitur report as spam yang membantu member untuk menyembunyikan atau mem-blok acara yang dirasa mengganggu. Contact the organizer diperuntukan agar user dapat dengan mudah untuk berkomunikasi dengan penyelenggara event.

e. Customer Relationship yaitu komunitas dan perguruan Tinggi dimana kerja sama dengan keduanya merupakan hal yang penting

f. Channels yang digunakan yaitu internet karena aplikasi yang dibangun adalah sebuah aplikasi yang berbasis web

g. Customer Segments dibagi menjadi 2 bagian besar yakni peserta event selaku pihak yang membutuhkan informasi event dan penyelenggara event yang berhubungan dengan konten yang akan melengkapi aplikasi dengan info, semakin lengkap info yang ada maka akan semakin ramai traffic aplikasi.

h. Cost Structure Biaya yang dikeluarkan yakni biaya IT dan Biaya pemasaran.

i. Revenue Stream berasal dari penjualan tiket yang disertakan pada event.

B. Analisa Kebutuhan

1. Kebutuhan Sistem

Kebutuhan sistem diperoleh dari proses kuisioner terhadap responden yang berasal dari mahasiswa, alumni dan masyarakat umum (Tabel I).

TABEL I ANALISIS KEBUTUHAN PESERTA ACARA

\begin{tabular}{|c|c|c|c|c|}
\hline No. & REQ ID & $\begin{array}{c}\text { Nama } \\
\text { Kebutuhan }\end{array}$ & Deskripsi & $\begin{array}{c}\text { Sumber } \\
\text { (User) }\end{array}$ \\
\hline 1 & REQ-01 & $\begin{array}{c}\text { Mengelola } \\
\text { peserta event }\end{array}$ & $\begin{array}{c}\text { Proses } \\
\text { pengelolaan profil } \\
\text { peserta event } \\
\text { menjadi Informasi }\end{array}$ & Administrator \\
\hline 2 & REQ-02 & $\begin{array}{c}\text { Membantu } \\
\text { pencarian } \\
\text { data event }\end{array}$ & $\begin{array}{c}\text { Proses pencarian } \\
\text { informasi event }\end{array}$ & $\begin{array}{c}\text { Anggota, } \\
\text { Pengunjung }\end{array}$ \\
\hline 3 & REQ-03 & $\begin{array}{c}\text { Membantu } \\
\text { menghubungi } \\
\text { penyelenggar } \\
\text { a event }\end{array}$ & $\begin{array}{c}\text { Proses } \\
\text { persunikasi } \\
\text { penyelenggara } \\
\text { event }\end{array}$ & $\begin{array}{c}\text { Anggota } \\
\text { Pengunjung, }\end{array}$ \\
\hline 4 & REQ-04 & $\begin{array}{c}\text { Mereport } \\
\text { event sebagai } \\
\text { spam }\end{array}$ & $\begin{array}{c}\text { Proses pelaporan } \\
\text { suatu event yang } \\
\text { tidak sesuai } \\
\text { menurut Anggota }\end{array}$ & $\begin{array}{c}\text { Anggota, } \\
\text { Administrator }\end{array}$ \\
\hline
\end{tabular}




\section{Aktor}

Aktor dalam sistem ini dibagi menjadi tiga bagian yakni, administrator, pengunjung dan anggota (Tabel II). Administrator memiliki hak akses khusus terhadap sistem yakni manajemen user. Anggota merupakan aktor yang dapat melakukan manjemen informasi miliknya masing-masing. Pengunjung hanya dapat melihat informasi yang disajikan kontributor atau penyelenggara acara.

TABEL II

PENDESKRIPSIAN AKTOR

\begin{tabular}{|c|c|c|}
\hline No & Nama Aktor & Deskripsi \\
\hline 1 & Administrator & $\begin{array}{c}\text { Aktor yang memiliki akses khusus } \\
\text { sebagai administrator sistem }\end{array}$ \\
\hline 2 & Pengunjung & $\begin{array}{c}\text { Aktor yang hanya dapat melihat } \\
\text { informasi dan jadwal acara }\end{array}$ \\
\hline 3 & Anggota & $\begin{array}{c}\text { Aktor yang memiliki kemampuan } \\
\text { dapat melakukan manajemen } \\
\text { informasi miliknya masing-masing }\end{array}$ \\
\hline
\end{tabular}

3. Use Case

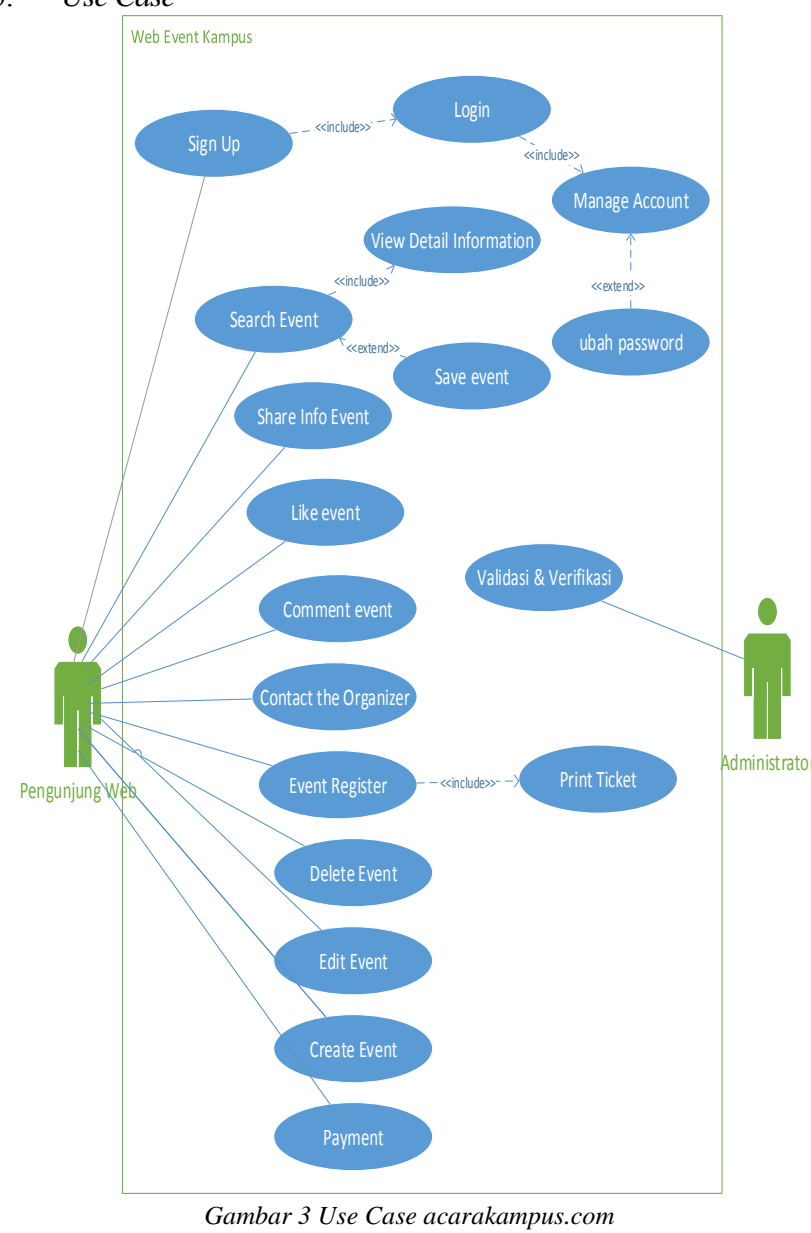

Use Case yang dibuat berdasarkan model bisnis yang telah dijabarkan pada pembahasan sebelumnya. Gambar 3 menggambarkan use case sistem secara keseluruhan dengan dua aktor utama yakni Pengunjung dan Administrator. Alasan yang mendasari aktor yang berperan pada usecase hanya administrator dan pengunjung saja dikarenakan pengujung dan anggota merupakan satu kesatuan dimana pengunjung memiliki akses untuk mencari informasi event dan membagikannya ke media sosial juga menghubungi penyelenggara event untuk menanyakan segala informasi yang diinginkan. Sementara apabila ingin bisa mengakses fitur keseluruhan di aplikasi ini pengunjung harus membuat akun atau menjadi Anggota. Anggota memiliki hak akses yang dimiliki pengunjung dan juga dapat membuat wishlist atau daftar event yang ingin dibuka dikemudian hari untuk mempermudah pencarian, mendaftarkan diri pada suatu event, memberikan rate pada event yang diikuti, mengelola profilnya sendiri. Administator memiliki akses khusus untuk dapat membuat dan mengelola akun, event, laporan spam, verivikasi dan validasi

\section{Class Diagram}

Pada tahap elaboration ini dipetakan class diagram yang berfungsi untuk mengetahui hubungan antar class-class dari web portal acarakampus.com. Pada class diagram dijabarkan bahwa terdapat class model yang terdiri atas 11 class yakni User, acara, Universitas, Kategori, Keranjang, Provinsi, Tiket, TransaksiTiket, TransaksiTiketDetail, Rekber dan class Controller yang terdiri atas 7 class yang terhubung ke BaseController sebagai controller yang berhubungan langsung dengan tampilan pada class View. Berikut merupakan class diagram yang telah dirancang dijabarkan pada gambar 4 yang terdapat lampiran.

\section{Conceptual Data Model (CDM)}

CDM dipakai untuk menggambarkan secara detail struktur basis data dalam bentuk logik. CDM terdiri dari objek yang tidak diimplementasikan secara langsung kedalam basis data yang sesungguhnya dimana dijabarkan hubungan antara tabel-tabel dari basis data portal web acarakampus.com yang terdiri atas 15 entity(tabel) yakni rekber, pesan, kategori, acara, wishlist, users, password_resets, universitas, kota, tiket, keranjang, tiket_transaksi, provinsi, tiket_transaksi_detail. Pada gambar 5 yang terdapat pada lampiran dijelaskan CDM dari portal web acarakampus.com yang dibangun.

\section{Physical Data Model (PDM)}

PDM pada lampiran gambar 6 merupakan gambaran secara detail basis data dalam bentuk fisik dari portal web acarakampus.com. Penggambaran rancangan PDM memperlihatkan struktur penyimpanan data yang benar pada basis data yang digunakan sesungguhnya yang terdiri atas 15 entity(tabel) yakni rekber, pesan, kategori, acara, wishlist, users, password_resets, universitas, kota, tiket, keranjang, tiket_transaksi, provinsi, tiket_transaksi_detail.

\section{Hasil Perancangan}

Pada bagian ini dijelaskan perancangan class yang telah diimplementasikan. Implementasi yang dimaksud adalah membuat aplikasi dari class diagram yang dirancang sebelumnya.Adapun class yang telah diimplementasikan dapat dilihat pada Tabel III. 
TABEL III

IMPLEMENTASI KOMPONEN

\begin{tabular}{|c|c|c|}
\hline MVC & Fungsi & Penjelasan \\
\hline \multirow{11}{*}{ Model } & Acara & $\begin{array}{l}\text { Class model yang berisi fungsi-fungsi } \\
\text { terkait dengan event }\end{array}$ \\
\hline & Kategori & $\begin{array}{l}\text { Class model yang berisi fungsi-fungsi } \\
\text { terkait dengan kategori }\end{array}$ \\
\hline & Keranjang & $\begin{array}{l}\text { Class model yang berisi fungsi-fungsi } \\
\text { terkait dengan pemesanan }\end{array}$ \\
\hline & Organisasi & $\begin{array}{l}\text { Class model yang berisi fungsi-fungsi } \\
\text { terkait dengan organisasi }\end{array}$ \\
\hline & Tiket & $\begin{array}{l}\text { Class model yang berisi fungsi-fungsi } \\
\text { terkait dengan tiket }\end{array}$ \\
\hline & Universitas & $\begin{array}{l}\text { Class model yang berisi fungsi-fungsi } \\
\text { terkait dengan universitas }\end{array}$ \\
\hline & Users & $\begin{array}{l}\text { Class model yang berisi fungsi-fungsi } \\
\text { terkait dengan user }\end{array}$ \\
\hline & $\begin{array}{l}\text { Transaksi } \\
\text { Tiket }\end{array}$ & $\begin{array}{l}\text { Class model yang berisi fungsi-fungsi } \\
\text { terkait dengan proses transaksi tiket }\end{array}$ \\
\hline & $\begin{array}{l}\text { Transaksi } \\
\text { TiketDetail }\end{array}$ & $\begin{array}{l}\text { Class model yang berisi fungsi-fungsi } \\
\text { terkait dengan proses transaksi tiket } \\
\text { secara detail }\end{array}$ \\
\hline & Pesan & $\begin{array}{l}\text { Class model yang berisi fungsi-fungsi } \\
\text { terkait dengan pesan ke penyelenggara }\end{array}$ \\
\hline & Rekber & $\begin{array}{l}\text { Class model yang berisi fungsi-fungsi } \\
\text { terkait dengan konfirmasi pemesanan }\end{array}$ \\
\hline \multirow{7}{*}{ Controller } & $\begin{array}{c}\text { Base } \\
\text { Controller }\end{array}$ & $\begin{array}{l}\text { Class controller yang berisi fungsi- } \\
\text { fungsi untuk operasi dasar bawaan } \\
\text { laravel }\end{array}$ \\
\hline & $\begin{array}{l}\text { Page } \\
\text { Controller }\end{array}$ & $\begin{array}{l}\text { Class controller yang berisi fungsi- } \\
\text { fungsi untuk operasi kemampuan peserta } \\
\text { event }\end{array}$ \\
\hline & $\begin{array}{c}\text { Cari } \\
\text { Controller }\end{array}$ & $\begin{array}{l}\text { Class controller yang berisi fungsi- } \\
\text { fungsi untuk operasi pencarian }\end{array}$ \\
\hline & $\begin{array}{l}\text { Account } \\
\text { Controller }\end{array}$ & $\begin{array}{l}\text { Class controller yang berisi fungsi- } \\
\text { fungsi untuk operasi Akun user }\end{array}$ \\
\hline & $\begin{array}{l}\text { Acara } \\
\text { Controller }\end{array}$ & $\begin{array}{l}\text { Class controller yang berisi fungsi- } \\
\text { fungsi untuk operasi pembuatan dan edit } \\
\text { event yang akan disajikan pada halaman } \\
\text { web. }\end{array}$ \\
\hline & $\begin{array}{l}\text { Order } \\
\text { Controller }\end{array}$ & $\begin{array}{l}\text { Class controller yang berisi fungsi- } \\
\text { fungsi untuk operasi pemesanan event }\end{array}$ \\
\hline & $\begin{array}{l}\text { Transaction } \\
\text { Controller }\end{array}$ & $\begin{array}{l}\text { Class controller yang berisi fungsi- } \\
\text { fungsi untuk operasi proses transaksi dan } \\
\text { konfirmasi tiket }\end{array}$ \\
\hline \multirow{11}{*}{ View } & $\begin{array}{l}\text { change_password.b } \\
\text { lade }\end{array}$ & $\begin{array}{l}\text { Halaman yang digunakan untuk } \\
\text { menyunting password akun } u \text { ser }\end{array}$ \\
\hline & edit_account.blade & $\begin{array}{l}\text { Halaman yang digunakan untuk } \\
\text { menyunting profil dan akun user }\end{array}$ \\
\hline & myaccount.blade & $\begin{array}{l}\text { Halaman yang digunakan untuk } \\
\text { menampilkan informasi akun }\end{array}$ \\
\hline & contact.blade & $\begin{array}{l}\text { Halaman yang digunakan untuk mengirimkan } \\
\text { pesan ke admin }\end{array}$ \\
\hline & login.blade & $\begin{array}{l}\text { Halaman yang digunakan untuk melakukan } \\
\text { login }\end{array}$ \\
\hline & forgotpass.blade & $\begin{array}{l}\text { Halaman yang digunakan apabila user lupa } \\
\text { password }\end{array}$ \\
\hline & register.blade & $\begin{array}{l}\text { Halaman untuk membuat akun pada web } \\
\text { portal }\end{array}$ \\
\hline & $\begin{array}{l}\text { tickethistory. } \\
\text { blade }\end{array}$ & $\begin{array}{l}\text { Halaman yang digunakan untuk menampilkan } \\
\text { tiket yang pernah dipesan }\end{array}$ \\
\hline & $\begin{array}{l}\text { wishlist. } \\
\text { blade }\end{array}$ & $\begin{array}{l}\text { Halaman untuk menyumpan event yang } \\
\text { ditandai }\end{array}$ \\
\hline & $\begin{array}{l}\text { eventreg. } \\
\text { blade }\end{array}$ & $\begin{array}{l}\text { Halaman yang digunakan untuk melakukan } \\
\text { registrasi pada suatu event }\end{array}$ \\
\hline & $\begin{array}{l}\text { Index. } \\
\text { blade }\end{array}$ & $\begin{array}{l}\text { Halaman untuk menampilkan event, search } \\
\text { dan penghubung dengan tampilan yang lain }\end{array}$ \\
\hline
\end{tabular}

D. Pengujian

Pengujian yang dilakukan adalah pengujian blackbox terhadap sistem, dimulai dengan membangun rencana pengujian, kasus uji dari rencana pengujian tersebut, kemudia diambil juga feedback dari user mengenai sistem ini.

1. Rencana Pengujian

Rencana Pengujian ini merupakan rancangan pengujian terhadap fungsionalitas terhadap sistem (Tabel IV).

TABEL IV

\begin{tabular}{|c|c|c|c|c|}
\hline No & Aktivitas & Pengujian & $\begin{array}{c}\text { Jenis } \\
\text { Pengujian } \\
\end{array}$ & Kode \\
\hline 1 & Sign Up & $\begin{array}{l}\text { Skenario benar } \\
\text { Skenario salah }\end{array}$ & $\begin{array}{ll}\text { 1. } & \text { Blackbox } \\
\text { 2. } & \text { Blackbox } \\
\end{array}$ & $\begin{array}{l}\mathrm{U} 1-01 \\
\mathrm{U} 1-02 \\
\end{array}$ \\
\hline 2 & Login & $\begin{array}{ll}\text { 1. } & \text { Skenario benar } \\
\text { 2. } & \text { Skenario salah }\end{array}$ & $\begin{array}{ll}\text { 1. } & \text { Blackbox } \\
\text { 2. } & \text { Blackbox } \\
\end{array}$ & $\begin{array}{l}\mathrm{U} 2-01 \\
\mathrm{U} 2-02\end{array}$ \\
\hline 3 & $\begin{array}{l}\text { Buka Event } \\
\text { detail }\end{array}$ & Skenario benar & Blackbox & U3-01 \\
\hline 4 & Bookmark & Skenario benar & Blackbox & $\mathrm{U} 4-01$ \\
\hline 5 & $\begin{array}{l}\text { Registrasi } \\
\text { event }\end{array}$ & Skenario benar & Blackbox & U5-01 \\
\hline 6 & $\begin{array}{l}\text { Contact } \\
\text { Organizer }\end{array}$ & $\begin{array}{ll}\text { 1. } & \text { Skenario benar } \\
\text { 2. } & \text { Skenario salah } \\
\end{array}$ & $\begin{array}{ll}\text { 1. } & \text { Blackbox } \\
\text { 2. } & \text { Blackbox }\end{array}$ & $\begin{array}{l}\mathrm{U} 6-01 \\
\mathrm{U} 6-02 \\
\end{array}$ \\
\hline 7 & Edit profil & $\begin{array}{ll}\text { 1. } & \text { Skenario benar } \\
\text { 2. } & \text { Skenario salah } \\
\end{array}$ & $\begin{array}{ll}\text { 1. } & \text { Blackbox } \\
\text { 2. } & \text { Blackbox } \\
\end{array}$ & $\begin{array}{l}\text { U7-01 } \\
\text { U7-02 }\end{array}$ \\
\hline 8 & $\begin{array}{l}\text { Ubah } \\
\text { password }\end{array}$ & $\begin{array}{ll}\text { 1. } & \text { Skenario benar } \\
\text { 2. } & \text { Skenario salah } \\
\end{array}$ & \begin{tabular}{|ll} 
1. & Blackbox \\
2. & Blackbox \\
\end{tabular} & $\begin{array}{l}\mathrm{U} 8-01 \\
\mathrm{U} 8-02 \\
\end{array}$ \\
\hline 9 & Searching & Skenario benar & Blackbox & U9-01 \\
\hline 10 & $\begin{array}{l}\text { Advanced } \\
\text { Searching }\end{array}$ & $\begin{array}{ll}\text { 1. } & \text { Skenario benar } \\
\text { 2. } & \text { Skenario salah } \\
\end{array}$ & $\begin{array}{ll}\text { 1. } & \text { Blackbox } \\
\text { 2. } & \text { Blackbox } \\
\end{array}$ & $\begin{array}{l}\text { U10-01 } \\
\text { U10-02 } \\
\end{array}$ \\
\hline 11 & Logout & Skenario benar & Blackbox & U11-01 \\
\hline
\end{tabular}

\section{2. $\quad$ Feedback Users}

Pengambilan feedback user mengenai portal web berdasarkan pada 6 buah skala. Hasil kuisioner yang disebar pada 16 responden dari kalangan mahasiswa dan masyarakat umum bertujuan untuk mendapatkan feedback mengenai aplikasi yang dibuat (Tabel V).

\section{Hasil Pengujian dan Feedback User}

Berdasarkan pengujian fungsionalitas portal web dan feedback user yang telah dilakukan, hasil yang diperoleh adalah sebagai berikut:

1. Fungsi yang diuji pada sistem berjalan dengan baik. Setiap input yang dimasukkan dapat diterima dengan baik, dan output sesuai dengan yang diharapkan.

2. Portal web yang dibuat dapat memenuhi semua fungsi yang dibutuhkan oleh user.

3. Portal web yang telah dibuat dapat mengakomodasi pengguna untuk berbagi informasi event.

4. Portal web yang dibuat dapat memberikan informasi terkait mengenai event pada halaman detail informasi.

5. Pengguna mendukung adanya portal web ini karena portal web ini memberikan nilai tambah kepada pengguna 
TABEL V

HASIL FEEDBACK USERS

\begin{tabular}{|c|c|c|c|c|c|}
\hline \multirow{2}{*}{$\begin{array}{c}\text { Nama } \\
\text { Dimensi }\end{array}$} & \multirow[t]{2}{*}{ Pertanyaan } & \multicolumn{2}{|c|}{$\begin{array}{c}16 \\
\text { responden }\end{array}$} & \multirow{2}{*}{\multicolumn{2}{|c|}{$\begin{array}{c}\text { Presentase } \\
(\%)\end{array}$}} \\
\hline & & $\mathrm{Ya}$ & Tidak & & \\
\hline \multirow{2}{*}{$\begin{array}{c}\text { Web } \\
\text { Design }\end{array}$} & $\begin{array}{l}\text { Apakah tampilan portal } \\
\text { web menarik secara } \\
\text { keseluruhan? }\end{array}$ & 11 & 5 & $69 \%$ & $31 \%$ \\
\hline & $\begin{array}{l}\text { Apakah menu dan } \\
\text { fungsi pada portal web } \\
\text { dapat dimengerti } \\
\text { dengan baik? }\end{array}$ & 11 & 5 & $69 \%$ & $31 \%$ \\
\hline \multirow{2}{*}{ Reliability } & $\begin{array}{l}\text { Apakah portal web } \\
\text { dapat mengakomodasi } \\
\text { user untuk mencari } \\
\text { informasi dan } \\
\text { mendaftarkan diri? }\end{array}$ & 13 & 3 & $81 \%$ & $19 \%$ \\
\hline & $\begin{array}{l}\text { Apakah portal web } \\
\text { memberikan informasi } \\
\text { terkait pada saat } \\
\text { menampilkan informasi } \\
\text { event secara detail? }\end{array}$ & 12 & 4 & $75 \%$ & $25 \%$ \\
\hline Responsiveness & $\begin{array}{l}\text { Apakah portal web } \\
\text { dapat memberikan } \\
\text { respon yang cepat } \\
\text { ketika diakses? }\end{array}$ & 13 & 3 & $81 \%$ & $19 \%$ \\
\hline Trust & $\begin{array}{l}\text { Apakah portal web } \\
\text { dapat dipercaya untuk } \\
\text { pembelian tiket? }\end{array}$ & 12 & 4 & $75 \%$ & $25 \%$ \\
\hline Personalization & $\begin{array}{l}\text { Apakah portal web } \\
\text { dapat memberikan nilai } \\
\text { tambah kepada } \\
\text { pengunjung? }\end{array}$ & 13 & 3 & $81 \%$ & $19 \%$ \\
\hline Attractiveness & $\begin{array}{l}\text { Apakah anda tertarik } \\
\text { untuk menggunakan } \\
\text { portal web ini sebagai } \\
\text { media informasi event } \\
\text { perguruan tinggi? }\end{array}$ & 13 & 3 & $81 \%$ & $19 \%$ \\
\hline
\end{tabular}

\section{KesimpUlan}

Beberapa kesimpulan yang didapatkan dari pengembangan portal event ini adalah sebagai berikut.

1. Portal web telah berhasil dibangun dengan konsep crowdsourcing di dalamnya sehingga mendukung peserta event untuk mendaftarkan diri pada suatu event di dalamnya.

2. Pengguna telah mendapatkan informasi event yang sesuai dengan preferensi yang dimasukkan.

3. Berdasarkan hasil feedback yang sudah dianalisis, portal web telah memberikan informasi sesuai dengan kebutuhan pengunjung

\section{DAFTAR PUSTAKA}

[1] Noor, A. (2013). Manajemen Acara. Bandung: Alfabeta.

[2] Soegianto, M.Y dan Sutanto, E.M (2013) Penerapan Strategi Alih Daya (Outsourcing ) di UD. Puyuh Plastik ditinjau dari Ketentuan Perundangan dan Etika Bisnis. Surabaya: Universitas Kristen Petra.

[3] Rational Software Development Company (1998). Best Practices For Software Development Time.

[4] PPM. (2012). Business Model Canvas Penerapan di Indonesia. Jakarta Pusat: PPM.

[5] Prakoso, Yogy. (2013). Membangun Portal Web Crowdsourcing Acara Menggunakan Metode Iterative \& Incremental Dan Metode Pencarian Vector Space Model. Bandung : Telkom University.

[6] Afif, A. Y. (2014). Membangun Sistem Informasi Call For Paper, Konferensi, dan Perlombaan untuk Akademisi Berbasis Web Crowdsourcing Menggunakan Metode Iterative Incremental. Bandung : Telkom University. 


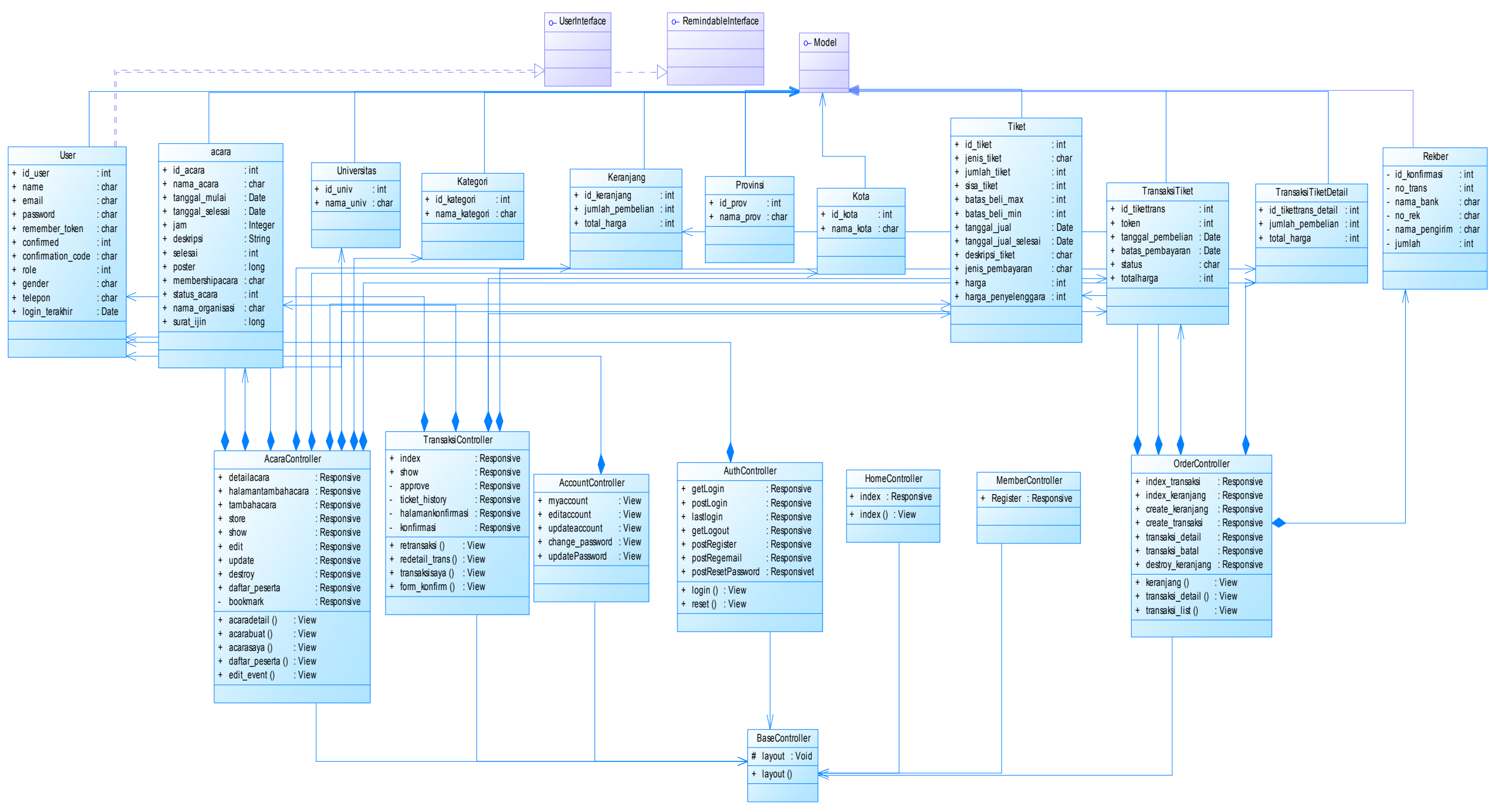

Gambar 4 Class diagram acarakampus.com

Pembangunan Portal Web Crowdsourcing Event Perguruan Tinggi Menggunakan Metode Iterative Incremental (Modul Peserta Event) Alifia Indra Damarani, Irfan Darmawan, Taufik Nur Adi (hal.8 - 16) 


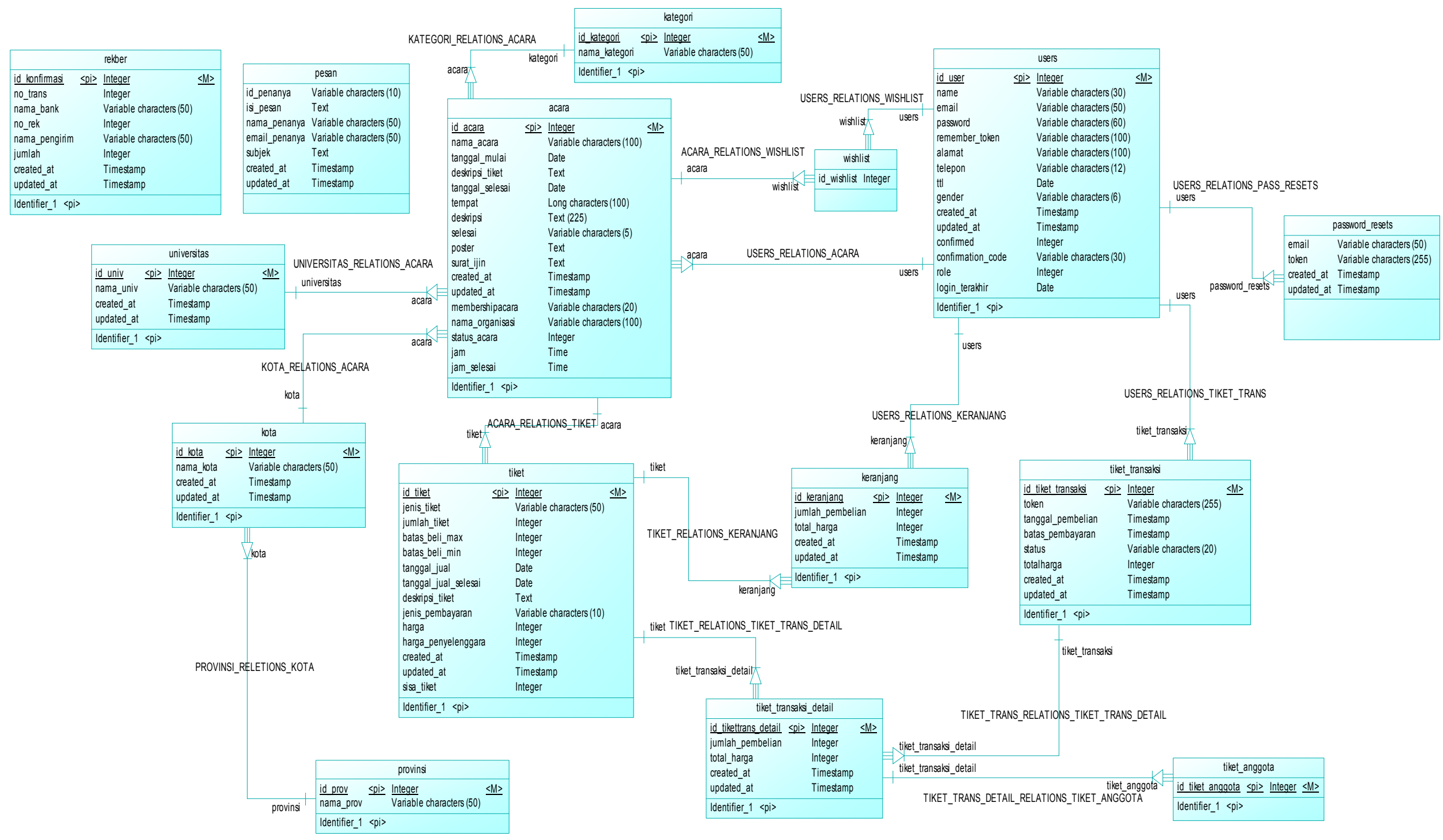

Gambar 5 CDM acarakampus.com

Jurnal Rekayasa Sistem \& Industri

Volume 2, Nomor 3, Juli 2015 


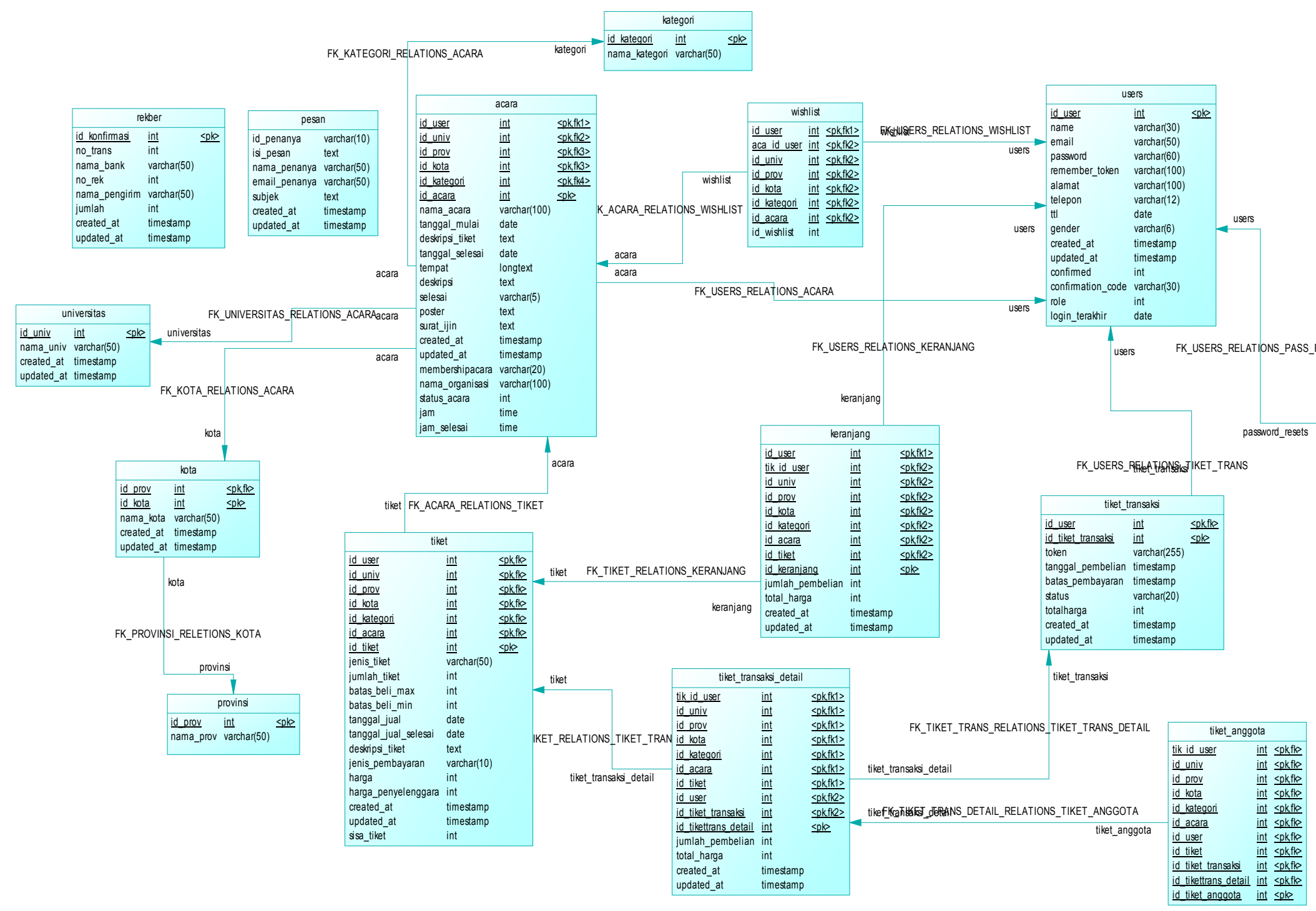

Gambar 6 PDM acarakampus.com

Pembangunan Portal Web Crowdsourcing Event Perguruan Tinggi Menggunakan Metode Iterative Incremental (Modul Peserta Event) 